\title{
コラーゲン固定化ポリエチレン多孔質材料の軟組織適合性の研究
}

\author{
葛原武

\section{The study on the soft tissue biocompatibility of collagen immobilized porous polyethylene}

\author{
Takeshi Kuzuhara
}

\begin{abstract}
A study has been made to determine the long-term effect of collagen-immobilized porous polyethylene on living body tissues as a result of reaction between them, and to clarify the ultramicrostructure in the interface between such a material and the tissues. Experiments were made using $70 \mathrm{Wister}$ rats. Collagen-immobilized porous polyethylene pieces, in which immobilization was attained through covalent bouding, and virgin porous polyethylene pieces were implanted subcutaneously in the backs of the rats. These polyethylene pieces were removed from the rats together with surrounding tissue from one week to one year after implantation, and were studied histologically using a light microscope, a scanning electron microscope (SEM) and transmission electron microscope (TEM). The results were as follows:
\end{abstract}

1) Virgin Porous Polyethylene

The rate of soft-tissue ingrowth into pores of these polyethylene pieces was very small, ranging from $13 \%$ to $18 \%$, in all of the rats. The ingrown tissue was composed of granulation tissue having many inflammatory cells, and hyalinezation was observed in parts of the tissue. As far as SEM observation is concerned, it was found that the collagen fibers in the ingrowth tissue run in parallel to the surface of the pore in the polyethylene pieces, and irrespective of the differences of implanted period no contact between them was observed. One year after the implantation, tumorous growth was observed in nine (45\%) of the 20 implanted virgin porous polyethylene pieces.

2) Collagen-immobilized Porous Polyethylene

The rate of tissue ingrowth into the porous polyethylene pieces stood at $23.2 \%$ one week after the subcutaneous implantation, $32.4 \%$ after two weeks, $60.2 \%$ after four weeks, $69.3 \%$ after six weeks, $81.6 \%$ after 12 weeks and higher than $90 \% 20$ weeks after implantation. One year after implantation there was little change in the percentage, and by that time the ingrowth tissue and the porous polyethylene pieces had turned into biocomposite. The ingrowth formed loose connective tissue abounding in rete vasculosum containing a relatively low level of inflammatory cells. SEMI observation found that the collagen fibers within the ingrown tissue were developing toward the pore surface of polyethylene material and coming in contact with the material surface. On the other hand, TEM observation of material-tissue interface found that one year after the implantation the living-body-originated collagen fibers were firmly anchored into the immobilized atero-collagen layer.

One year after implantation, tumor formation was found in only one $(5 \%)$ of the

神奈川蔽科大学口腔外科学教宝

（主任：志村介三教授）

Department of Oral Surgery, Kanagawa Dental
College (Chief: Prof. Kaizo Shimura)

受付日：平成 3 年 1 月 31 日 
20 polyethylene pieces removed from the rats representing virgin porous polycthylene use. These results suggest that covalent bonding immobilization of collagen onto surface of porous polyethylene material is useful in promoting the ingrowth of soft tissue, tissue-adhesion, and inhibition of tumorigenesis, making porous polyethylene material more suitable for introduction into the living body.

Key words: collagen-immobilization (コラーダン固定化), porous polyethylene (多孔镇ポリニ チレン), soft-tissue compatibility（軟組織適合性）

緒

言
実 験 方 法
近年，生体材料の進歩はめざましく，顎口腔領域にお いても人工歯根材や顎骨再建材としてさまざまな硬組織 代替材料が開発され，㓞際の臨床に用いられている。 し かし，それらはもっぱら骨適合性のみに重点が笽かれ， 軟組織適合性についてはあまり重要視されていない。な かでも，現在最も広く臨床に応用されているヒドキシ アパタイトやチタンなどの材料は，骨組織との化学結合 や軟組織を介さない直接的結合をもたらす反面, 軟組織 との結合性を欠き，軟組織と接するところては例外な く, 楾維性被膜によって被包化される1)このような材 料の軟組織との結合性の欠如は，人工柬根に㧍ける上皮 の深部增殖の助長，あるい:人工靧や骨補填材における 被覆軟組䅧の非藩化や軟組織界面での死腔の形成や感染 を引き起こし，ひいては材料の撒去や重篤な術後合併症 の原因ともなっている。したがってこれらの人工材料 が長期間，生体内で安定して機能を営もには，骨適合性 たけでなく，軟組織との結合性ていかに付与し，これと 調和させるかが重要な課題となってきている，最近，人 工材料の表面に各種細胞接着性物質を固定化させること により，材料自身を直接生体組織と接着させるという表 面改質の方法が試みられている年 な) なかでも玉田，阔 田 $^{4,5)}$ ら: コラーゲンやその他の接着性タンパク質を人 工材料に共有結合によって固定化する方法を開発し，往 来の材计にみられない軟組織結合能を得た。

しかしこのようなコラーゲン固定化法が臨床に活用 できるよらになるためには，その結合様式の詳細を明ら かにするとともに，てれが長期間維持されるかとらかが 重要である.

本研究ではここれらの点を明らかにするためにホリエ チレン多孔質材料にコラーダンを固定化したものについ て，1年間にわたる皮下埋入史駼により，軟組織反応の 組織学的観察之材料・組織界面の超微細棈造について検 討した。

\section{1. 実験動物}

奏駼動物は体重䄪 $200 \mathrm{~g}$ の Wiser 采ラット堆, 8 週 䁖，70匹を用い室温 $21 \sim 26^{\circ} \mathrm{C}$, 混度 $45 \sim 55 \%$ の恒温标 物室で 1 週間健康状態空観察したのち奏騒に供した。飼 有条件として金属ゲージに 2 匹ずつ入れ，才リエンタル

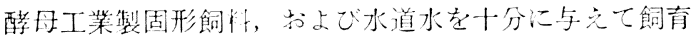
した。

\section{2. 材料のコラーゲン固定化の方法および 試料の調製 方法}

夹駼材料として三和化工製の速釉気孔ホリエチレンス ポンジオプセル LC 300 ?2 (平均孔径䄪 $400 \mu \mathrm{m}$ ) を 用いた。これを大きさ $5 \times 10 \times 15 \mathrm{~mm}$ に切断してメタ， ール中に24時間浸漬し，不純物を抽出除去した。コラー ゲン固定化の方法は Suzuki ${ }^{6)}$, 王田 ${ }^{4)}$, Okada 5 ${ }^{5)}$ の方 法に準じて行った。まお゙，材料に空気中のグロ一放電に よるプラズマ処理を0.04 Torr, 24 いにて15秒間行った。 ついで真空下でプラズマ処理村料表面にアクリル酸をク ラフト重合させた後, 水溶性カルボジイミトにてホリア クリル酸のカルボキシル基にコラーゲン分子を共有結合 させた、コラーゲンはあらかじあ抗原性を除去したアテ ロコラーゲン（新田ゼラチン製セルマトリックス，係皮 由来の 1 型）を用いた。ブラズマ処理は，島津製作所製 プラズマ重合装置 LCVD-20を用いた。

生体埋入材料の消毒はサクラ精機社製酸化エチレンカ ス減菌装置EOA-150型にてエチレンオキサイト減菌後， サクラ精機社製エアレーター EGF-500 型にてェアレー ションを十分に行った。去，コラーゲン末処理村料を 対照群として同様に調製し，消茾した。

\section{3. 埋入方法}

埋入方法は，エーテル瞅酔下にてラット背部の别毛と

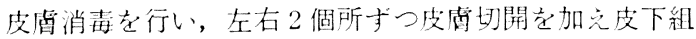

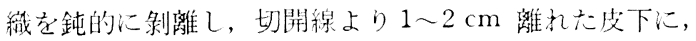
コラーゲン固定化試料と末処理試料を対称的に2 個ずつ 計4個埋入して，切開部夌絹采にて縫合閉鎖した。術百 後, $33 \mathrm{mg} / \mathrm{kg}$ のアンピンリン（明治整菒, ビクシリン） を腹腔内に注射した。 


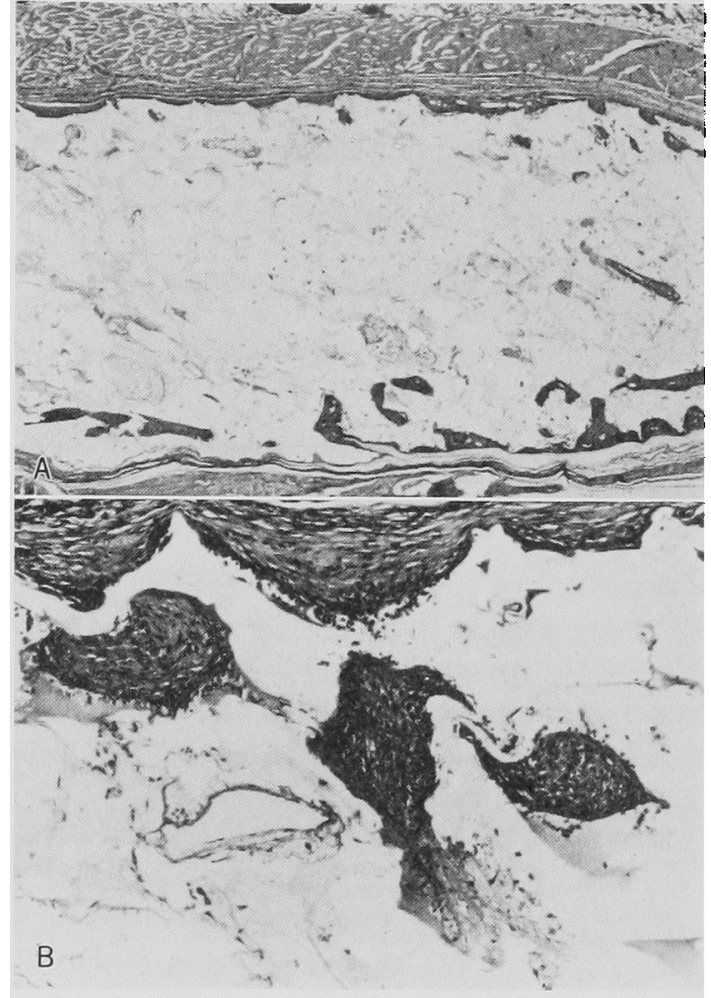

写直 1 末処理群埋入後 1 週光顕所見(H-E 染色)

A : 気孔内への組織の侵入忙こくわずかである( 4).

B：材料扨縁の気孔内に侵入した肉芽組織には，中 等度の炎症性細胞浸潤と多核巨細胞が認少坑 る $(\times 100)$.

\section{4. 観察方法}

\section{1) 肉眼的観察}

試料埋入後，最長 1 年にわたり創部の観察と体重測定 を行ったまなた屠殺時には，試料とその周囲組織の割断 面を肉眼的に観察した。

2) 光学題微鏡による組織学的観察

1，2，4，6，12，20週，1年とし，各時期に10匹ずつ 屠殺し、試料と周囲組織を一塊として切除した。つい 通法に従って10\%中性ホルマリン緩衝液で固定した後， パラフィン包埋を行い， $4 \mu \mathrm{m}$ の組織切片を作製し， 一 マトキシリンーエオジン染色 (H-E 染色) を施し鏡検し た。

また，埋入12週と20週後ラットの一部に対して墨汁注 入法による血管像の観察を行ったまずラットの下大動 脈から $5 \%$ ぜランン加悬汁を注入しぜラチン硬化後，パ ラフィン包理を行った. ついで $100 \mu \mathrm{m}$ 厚切り切片を作 製後，H-E 染色を施し，気孔内を鏡止した。

気孔内への組織侵入度は，試料の中心部断面における

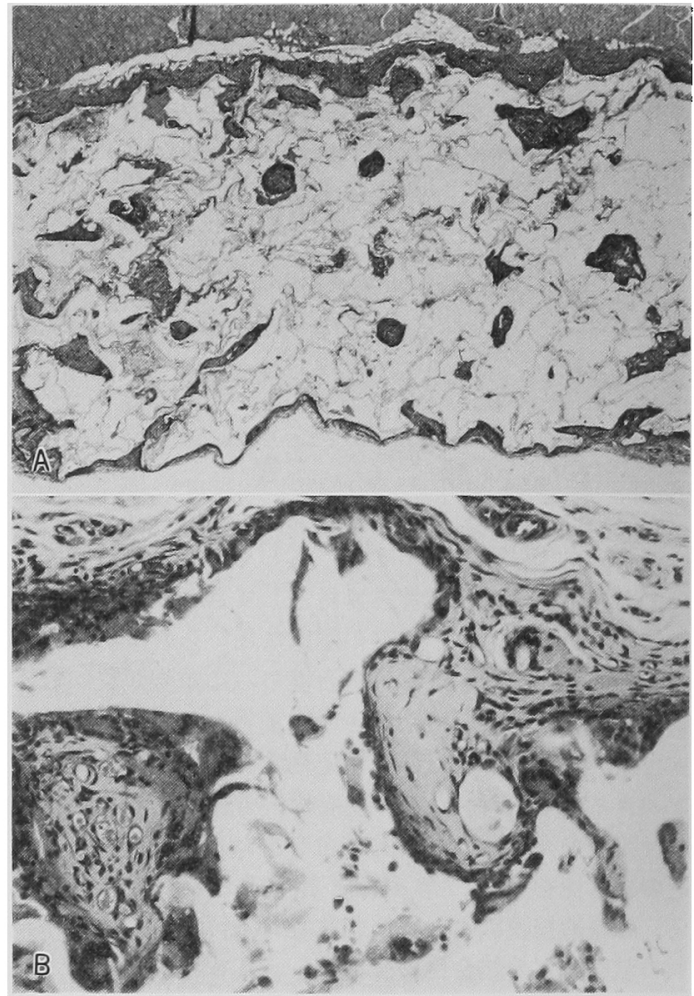

写真 2 末処理群埋入後 2 週光影所見 (H-E 染色)

$\mathrm{A}$ ：組織の侵入はこくわずかである(×4).

B：材料周囲から気孔内に侵入した肉芽組織内には, 多核巨稩胞が多数認められる $(\times 200)$.

顕徽鏡写真から侵入組織をトレースし, 気孔全体の面積 に対する侵入組織の占有率をニレコ社製画像解析装置 LUZEX 500によって計測した。

3 ）電子影徽鏡による観察

(1) 走査型電子顕诫鏡 (SEM) による観察

埋入後 6,20 週，1年の固定化群および未処理群の試 料の一部を $2.5 \%$ グルタルアルデヒドと四酸化オスミウ ムにより二重固定し，エタノール脱水の後，酢酸イソフ ミルにより置換して日立 HCP-2 形による臨界点乾燥を 行い,エイューエンジニアリング製 IONCOATER で 白金パラジウム蒸着後，日本電子製 JSM-35Cにて観察 した.

（2）透過型電子顕微鏡（TEM）による観察

埋入後 6,20 週, 1 年の固定化群の試料の一部を約 1

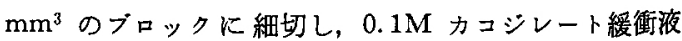
(pH 7.2) を用いて調整した $2.5 \%$ グルタルアルデヒド (1\%タンニン酸加)にて1〜1.5 時間前固定を行った。 いで $1 \%$ 四酸化オスミウム酸(1.5\%フェロシアン化カリ 


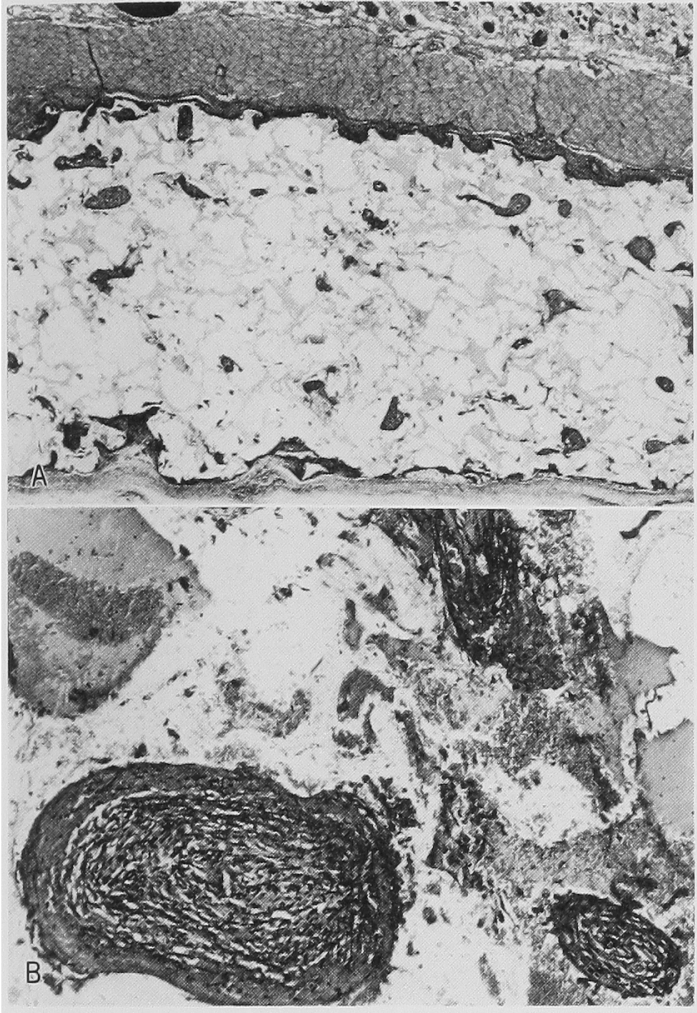

写真 3 末処理群埋入後 4 週光顕所見 (H-E 染色)

A：気孔内に肉芽組織が散在性に認められる $(\times 4)$.

B：気孔内の肉芳組織と出血巣扣よび溘出液。肉芽 組織と気孔隔壁とは離開している（×100）。

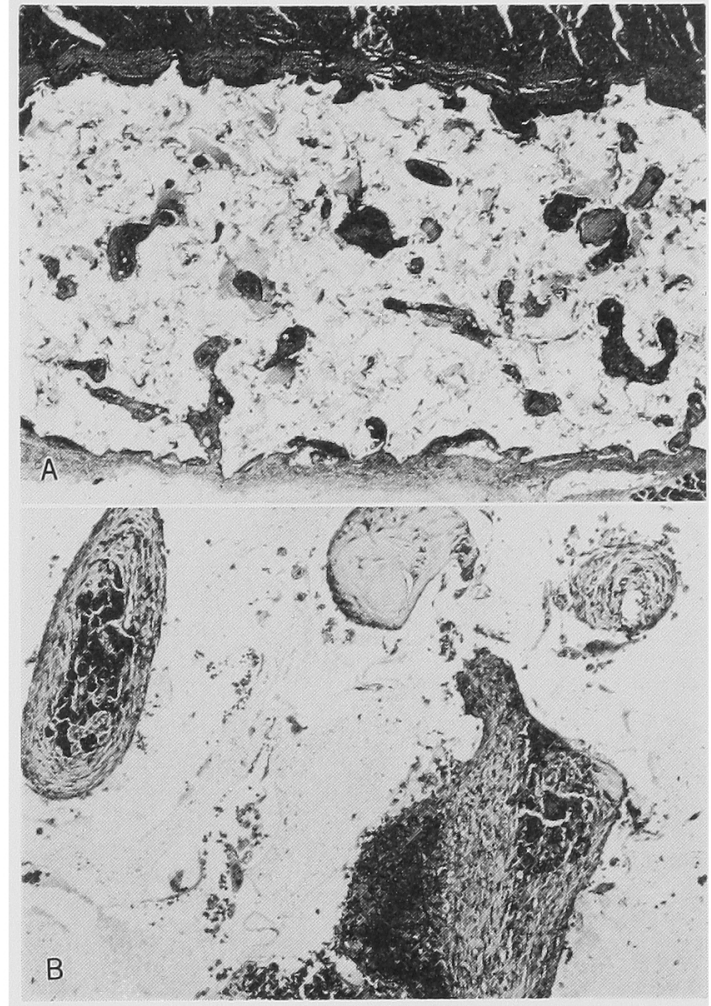

写真 4 未処理群埋入後 20 週光顕所見 (H-E 染色)

A：被膜の線維化がみられるが，唚入組織はわずか である $(\times 4)$

B：気孔内の肉芽組織には硝子化，へモジデリンの 沈着がみられる。組織と材料隔壁とは離開して いる $(\times 100)$.

ラーゲン固定化群では，4 週以後，気孔の大部分は白色 を呈する軟性充実性の組織で満たされていた。

\section{2. 組織学的観察結果}

1) 末処理群

埋入 1 週後 : 材料周囲には線維芽細胞と毛細血管の増 殖を伴った肉芽組織が形成され，リンパ球を主とする中 等度の炎症性細胞浸潤と多数の異物巨細胞が認められ た，材料気孔内への結合組織の侵入は表層の一部に認め られるのみで, 気孔内にはフィブリン析出と出液の貯 留が認められた（写真 1$)$.

埋入 2 週後：材料周囲では部分的に線維性被膜による 被包化すみられるが，全体的には 1 週目と同様な炎症性 細胞浸潤と多核巨細胞を伴った肉芽組織が認められる. 気孔内への組織侵入量も 1 週時と変わらず，依然として 気孔のほとんどは淬出液で満たされている(写真 2).

埋入 4 週後：材料周囲では肉苸組織の線維化が進んで いるが，炎症性細胞浸潤もかなり残存し，材料に接して 多核巨細胞がみられる。気孔内への組織侵入量はほとん 


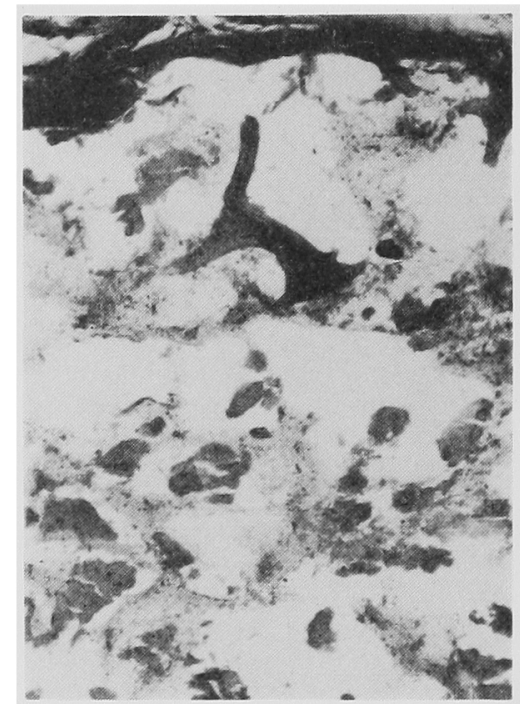

写真 5 未処理群埋入後 20 週

墨汁注入法による血管像の光 顕所見 (H-E 染色, $\times 40)$

被膜と気孔内の毛細血管網，気孔内での毛細血 管網の形成は之しい。

と゚変わらず，気孔内の組織占有率は約 $14 \%$ K過ぎない （写真 3A），侵入した組織には依然として炎症性細胞浸 潤中異物巨細胞が多く認められ，ところによって出血宩 や硝子化を示亦部分も認められた。 また線維の走行は同 心円状となり，組織と材料面とは離開している（写真 $3 \mathbf{B}$.

埋入 6 週後から20週まで：埋入 6 週以後20週までは同 様な組䅧所見を示した。すなわち材料周囲の肉芽組織は 線維化が進んではいるが，その被膜内にはリンパ球を主 とする軽度〜中等度の炎症性細胞浸潤やへモジデリンの 沈着扣よび組織球が認められ，とこるによって多核巨細 胞もみられる。気孔内への結合組織の侵入量は $2 \sim 4$ 週 とほとんど変わらず（写真 4A），侵入した組織には中 〜高度の炎症性細胞浸潤，へモジデリンの沈着括よび多 核巨細胞が認められ，高度の硝子化を示す部分もみられ る。また，侵入した結合組織と材料との接合は依然とし て認められない，結合組織の侵入のみられない気孔内は 苳出液ないし血球で満たされている（写真 4B）。畦汁 注入法による観察では12，20週とも同様で，材料周团で は線維の走行に沿って毛細血管網が形成されているが，

気孔内には散在的に孤立して認められるに過ぎない（写 真 5 ).

埋入 1 年後 : 腫瘤の形成のみられない 11 試料のちち 10 試料では，20週後と同様の所見を示したが（写真 6A）, 残りの 1 試料では材料の周囲組織, 気孔内に侵入した組 織内に異型細胞が認められた（写真 $6 \mathbf{B}$ )。

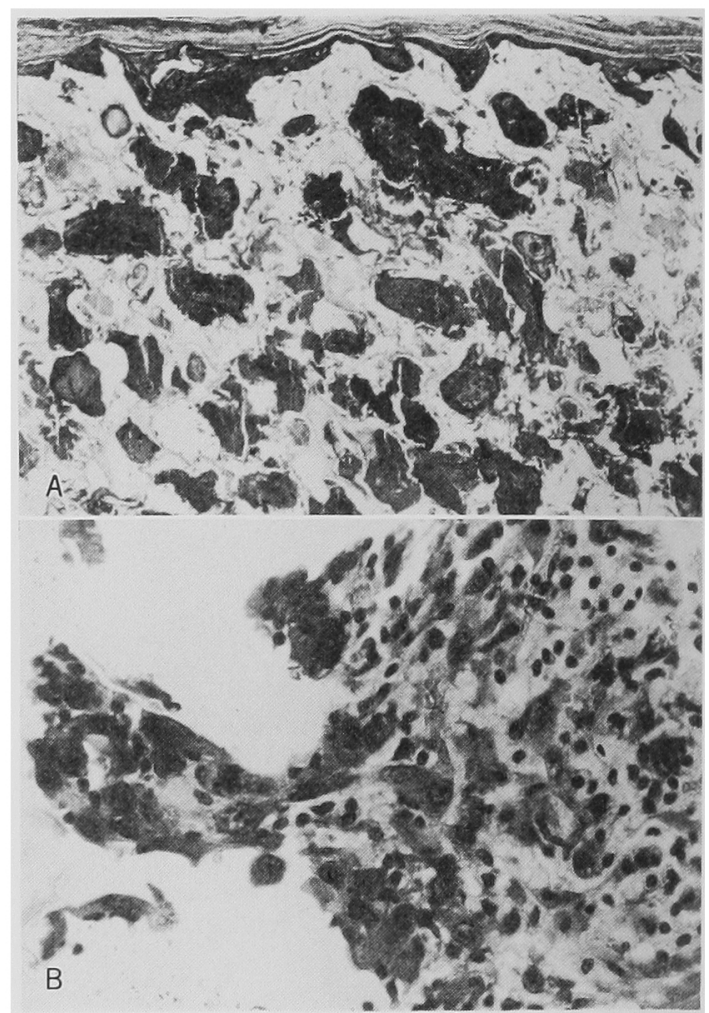

写真 6 未処理群埋入後 1 年光顕所見 (H-E 染色)

A：組織の侵入はわずかで，気孔の大部分は济出液 と出血栄で满たされている(×4).

B : 気孔内の肉茅組織, 異型稩胞が認められた $(x$ 100).

腫瘤を形成した 9 試料では，扣すに村料周用から気孔 内あるいは筋層内に線維性の腫場組織の増殖がみられる （写真 7B). 腫湟細胞は異型的な線稚芽細胞様細胞と組 織球性細胞扣よび巨細胞などからなり，ヒトの悪性線維 性組鐡球腫にきわ力て類似していた（写真 $7 \mathbf{C}$ ).

2) コラーゲン固定化群

埋入 1 週後: 材料は中等度の炎症性細胞浸潤を伴った 肉芽組織ないし線維性被膜てよって囲まれている。材料 の表層部では被膜から気孔内に向かって連続的に幼若な 結合組織が侵入し，それに粼接する気孔内には線維菜の 析出ないし液の貯留がみられる（写真 8).

埋入 2 週後：材料周囲では線維珄組織による被包化が 進み，炎症性細胞浸潤も減少傾向であるが，多核巨細胞 も散見される．気孔内への組織の侵入は1週時よりも増 加乙，材料中心部に向かって侵入しているが気孔の約 2/3は空疎となっている（写真 $9 \mathbf{A}$ ）。気孔内への侵入組 織は軽度のリン八球の浸潤と活発な線維芽細胞の增殖を 示す幼若な疎性結合織からなっており，これらの組織と 材料隔壁とは䎹に接している（写真 9B). 

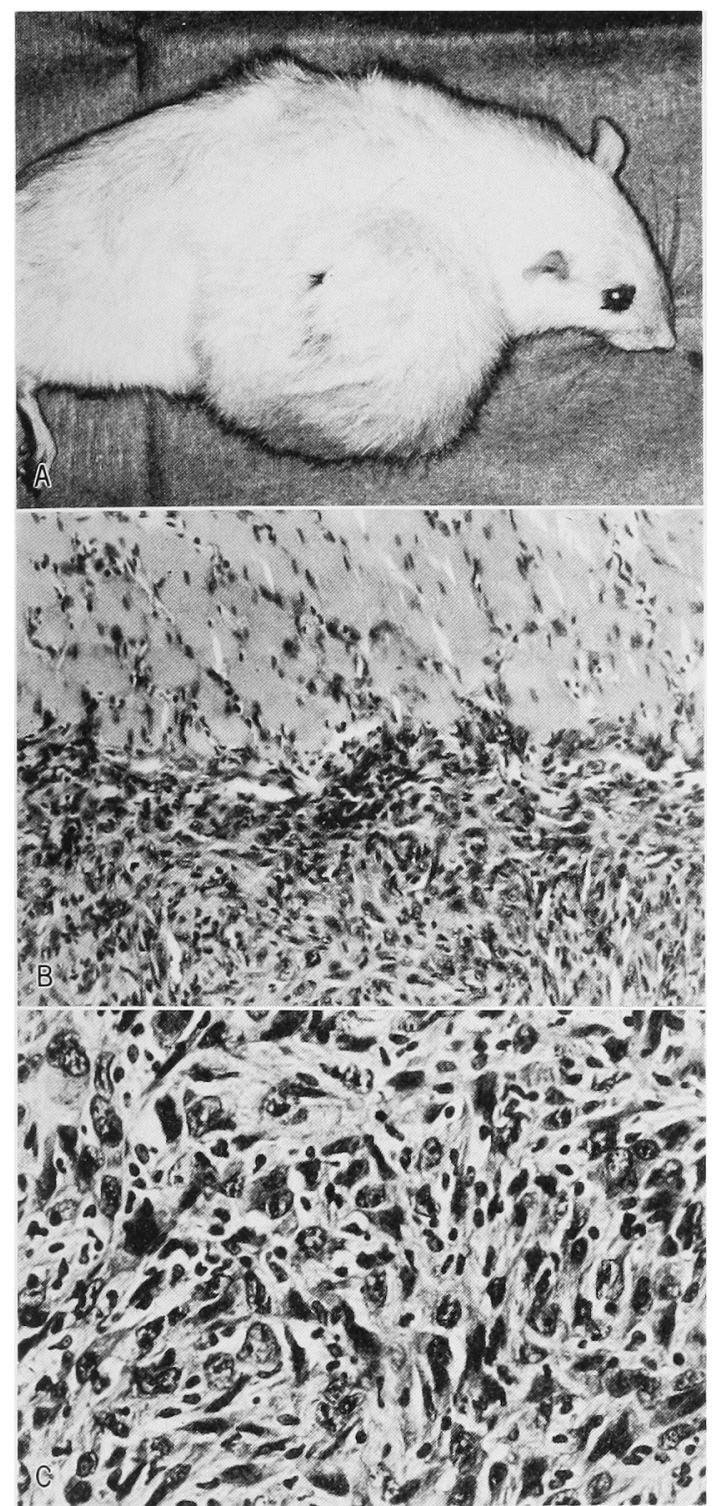

写真 7 未処理群埋入後 1 年所見

$\mathrm{A}$ ：腫喈形成したラット。

B : 筋層に浸潤した腫痬(H-E 染色， ×100).

C・腫瘍の組織像。異型的な線維芽細胞様細胞，組 織球性細胞扩よび巨細胞が認められ，ヒトの悪 性線維性組織球随に酷似している（H-E染色， $\times 200$ ).

埋入 4 週後：材料周围の炎症性細胞浸潤はほとんど消 退し，材料は薄い線維性被膜に被包されているが（写真 10B），部分的に軽度のリンパ球の浸潤拈よび多核巨细 胞が認められる。気孔内への組織の侵入はさらに進んで いるが，材料中心部には空眯な気孔が残存している（写

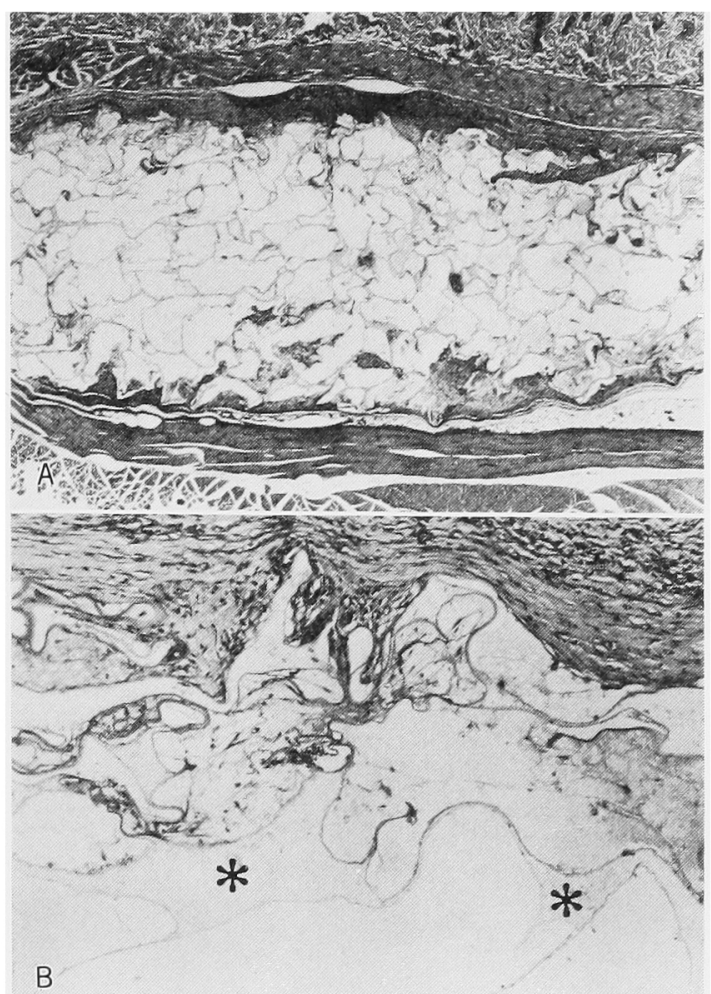

写真 8 コラーゲン固定化群埋入後 1 週光顕所見 (H-E 染色)

A：材料は肉芽組織ないし線維性組織によって曲ま れている $(\times 4)$

B：被膜から気孔内に向かって結合組織が侵入し， それに隣接して線維素の析出がみられる $(\times 100)$. （*印は材料融壁を示す）

真 $10 \mathrm{~A}$ ). 気孔内へ侵入した組織は毛細血管に富み, 線 維芽細胞の增殖と線維の形成が活発である。線維は材料 の隔壁に向かって走行し，材料表面と密に接しているの が認められる（写真 $10 \mathrm{C}$ ).

埋入 6 週後 : 材料は線䧽性の被膜で囲まれているが, 材料に接して少数ながら多核巨細胞方認められる。気孔 内への組織侵入はさらに進み, 気孔の約70\%に達してい る(写真 $11 \mathbf{A}$ )。侵入組織は毛細血管に富み，軽度のり ンパ球浸潤を伴う線維性結合組織からなり, 組織と材料 隔壁との結合状態は良好である（写真 $11 \mathrm{~B}$ ）。

埋入12週後 ・材料は 6 週時と同樣な線維性被膜で围ま れ, 気孔内の約 $80 \%$ は結合組織で満たされている（写直 12A). 気孔内の組織の大部分は細胞成分の比較的乏し い眯性結合組織からなるが，表層の気孔内には脂肪組織 も認められる(写真 12B)。 また気孔内に:依然として， ところどころに多核白細胞が出現しているが, コラー ゲン線維は材料隔壁に向かって走行し材料と組織は密に 


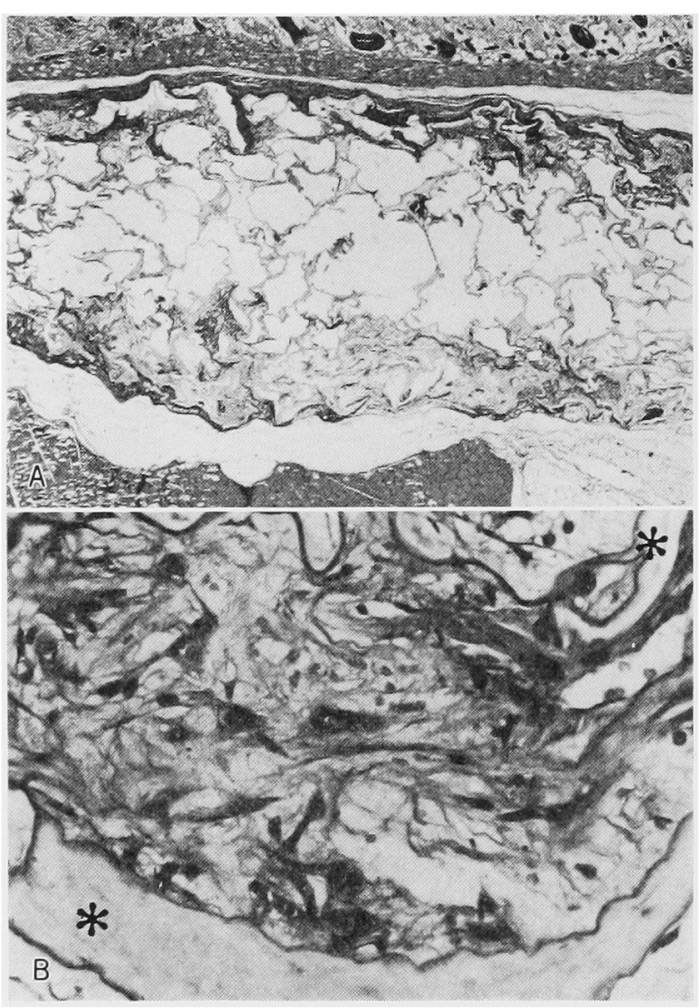

写真 9 コラーゲン固定化群理入後 2 週光影所見 (H-E 染色)

A . 気孔内の結合組織は 1 週時よりる増加している $(\times 4)$.

B：気孔内に侵入した組織と材料隔壁とは密に接し ている $(\times 400)$.

（＊印は材料滆壁を示す）

接している.

墨汁注入法による観察では，材料周囲の被膜内から毛 細血管が気孔内に侵入し，材料の中心部まで形成されて いる(写真13).

埋入 20 週後: 村料は線䧽性組織の被膜で囲まれ，気孔 内は12週時と同様の蹯性結合組織あるいは脂肪組織て満 たされている(写真14).

墨汁注入法による観察では気孔内の毛細血管は12週よ りもさらに增加し複雑，多樣に分岐，吻合した毛細血管 網が形成されている（写真15）。

埋入 1 年後：腫漡が形成しなかった試料では，村料は 軽度の炎症性細胞浸潤を伴う薄い線維性被膜に囲まれて いる. 気孔内線維性の結合組織で満たされているが, 20週時と比べて線維はやや太く密度を增し，ところどこ ろにリン八球の浸潤と異物巨細胞が認められる。しかし 毛細血管の量はかなり豊富で，組織と材料隔壁は传然と して密に接している（写真16）。残りの1例に未処理群
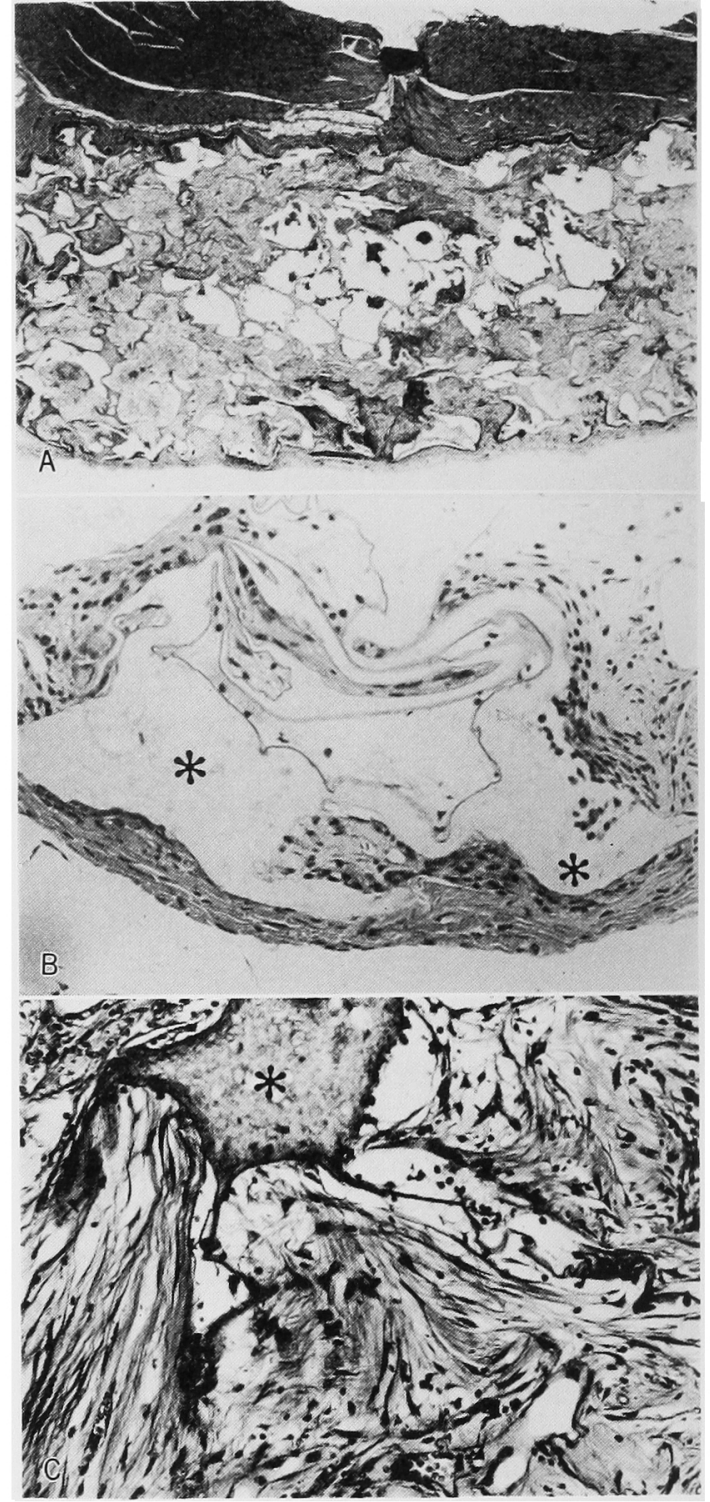

写真 10 コラーゲン固定化群埋入後 4 週光影所見 (H-E 染色)

A 気孔内の組織の侵入度は䄪 $60 \%$ に達している $(\times 4)$

B：材料は薄い被膜に澓われている(x100)

$\mathrm{C} \cdot$ 気孔内に侵入した組織は毛細血管に富み，活発 な線維の形成がみら机る。組織と材料は密に接 している $(\times 200)$.

（*印は村料隔壁を示す） 


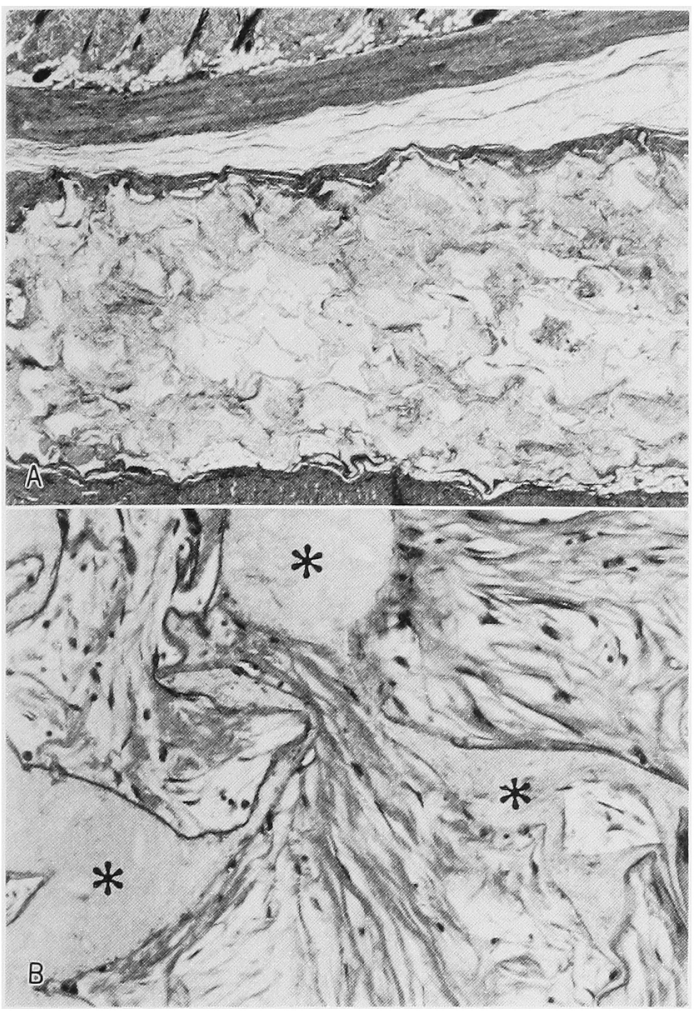

写真 11 コラーゲン固定化群埋入後 6 週光顕所見 (H-E 染色)

A：気孔内の約 70\% は結合組織で満たされている $(\times 4)$.

B：気孔内の资症性勫胞浸潤はごくわずかで，結合 組織と材料隔壁との結合状態は良好である(x $100)$.

（＊印は材料隔壁を示す）

之同様の腫窇が形成されている.

気孔内への組織侵入度は，未処理群では埋入 1 週から 1 年までは約 $15 \%$ とほとんど变化がみららない，一方コ ラーゲン固定化群では，1週後の組織侵入度は平均約 20 \%であるが，以後は増加し12週で約 $80 \% ， 20$ 週で90\%以 上に達し，その状態が 1 年後まで持続している（图 1).

3. 材料と組織 との界面における電子顕微鏡的観察結 果

1) 未処理群

埋入後 6,20 週， 1 年とも基本的には同一の SEM 像 を示している。すなわち，侵入組織のコラーゲン線維は 材料隔壁と平行に走行し，材料との結合は全く認められ ない(写真17)。

2) コラーゲン固定化群

埋入 6 週後の SEM 像では，形成されたュラーゲン線 維が束状をなして材料隔壁に垂值に走行し，材料面に付

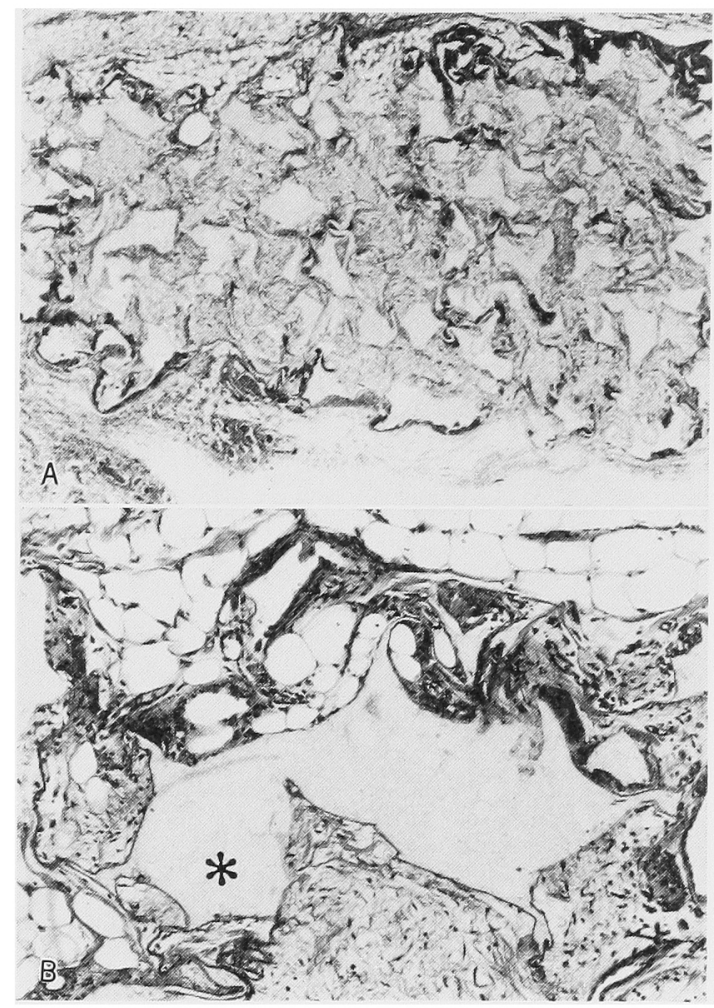

写真 12 コラーゲン固定化群理入後 12 週光顕所見 ( $\mathrm{H}-\mathrm{E}$ 染色)

A：気孔内はほほ全域にわたり蹯性結合組織と脂肪 組織で满たされている $(\times 4)$.

$\mathrm{B}$ : 表層の気孔内には脂肪組織の侵入がみられる $(\times 100)$.

（＊印は材料隔壁を示寸）

着して結合しているのが認められる．埋入 20 週後も 1 年 後も6週後と同様な像を示している(写真18)，TEM 像 では， 6 週後に周期構造の明瞭なコラーゲン線維が固定 化されたアテロコラーゲン層のなかに絡みあうように形 成されている。埋入 20 週後も 1 年後も 6 週後之基本的に は同様な像を示している（写真19）。

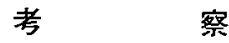

\section{1. 軟組織適合性について}

これまで人工材料の組織適合性については，おもに骨 組織に対する観点から検討されて和り，軟組織適合性に 関する報告は少ない。

人工材料が軟組織適合性をるつためには，まず (1) 軟 組織と結合能を有すること, (2) 周囲軟組織の正常な分 化・機能を阻害しないことが必要で市る。 
一般飞生体内に埋入される人工材料に組織結合能を付 与するためには，材料炕対灾する組織の主要な構成成分 と同一もしくは類似の化学構造をもたせることが，現時 点では最も合理的な方法と考光られている。 この点コ ラーダンは，軟組織の細胞外基質の主要な楧成成分であ り，細胞，組織の分化・増殖の足場としても重要な役割 を演していることが知られているて9) こうした観点か ら，近年材料表面にコラーゲン分子を固定化することに

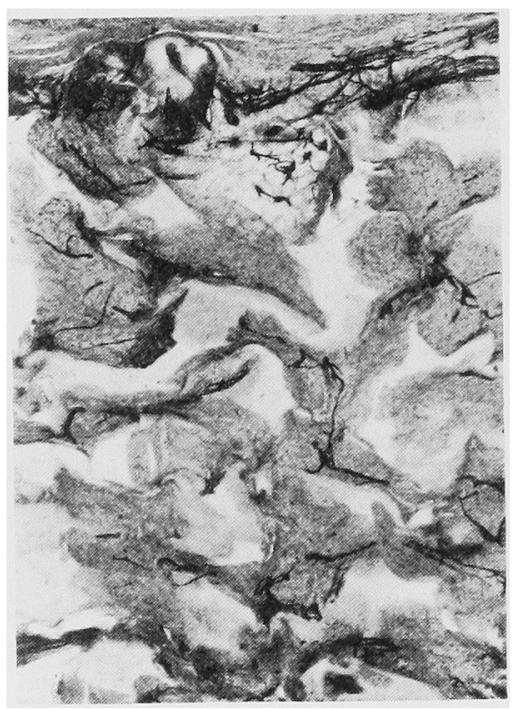

写真 13 コラーゲン固定化群埋入後12週 墨汁注入法による血管像 $(\mathrm{H}-\mathrm{E}$ 染色， $\times 40$ )

材料周囲の被膜から毛細血管が気孔内に侵入し，材 料の中心部まで澾している。

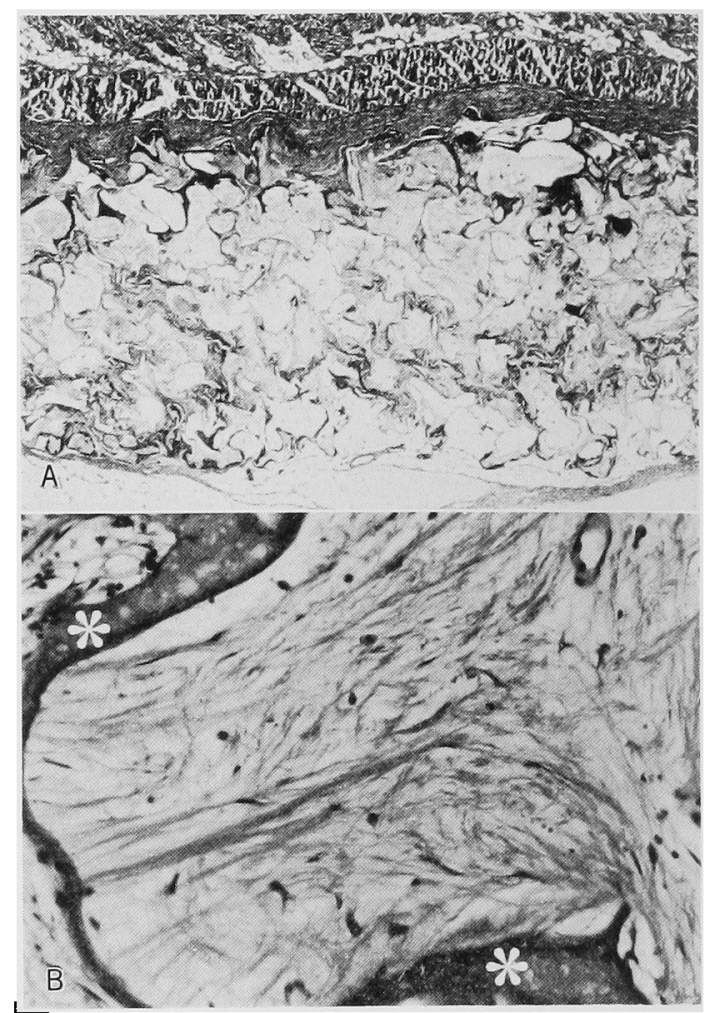

写真 14 コラーケン固定化群埋入後20週光頭所見 (H-E 染色)

A：12週と同様に気孔内は全域にわたり結合組織ぬ るい性脂肪組織で满たされている $(\times 4)$.

B：侵大乙た蹯性結合組織には炎症性細胞浸潤は注 とんどみられない $(\times 200)$. （*印恃材料隔壁を示す）

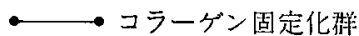
○- - ○刘照群

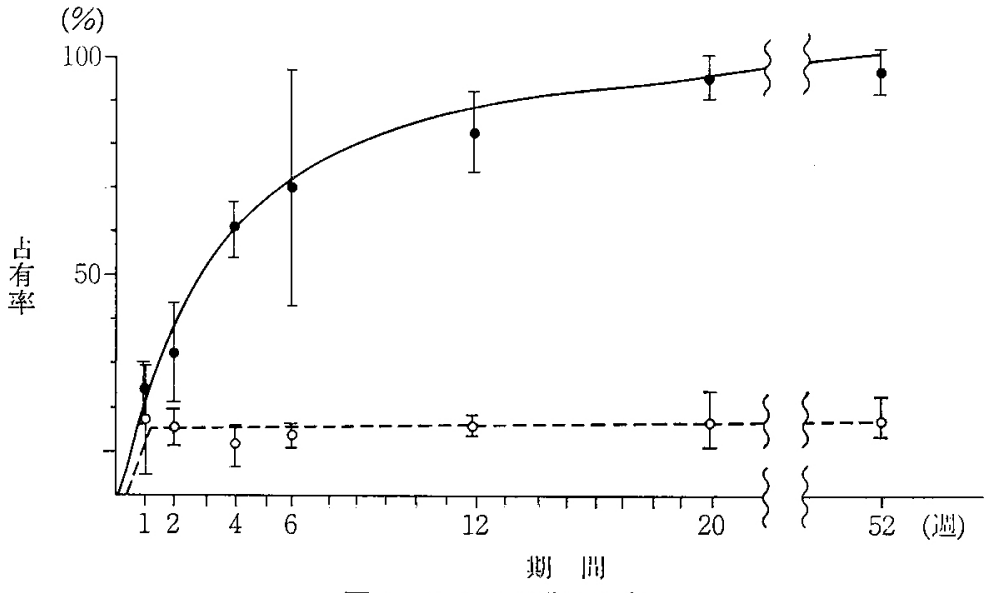

図 1 気孔内組織侵入度 


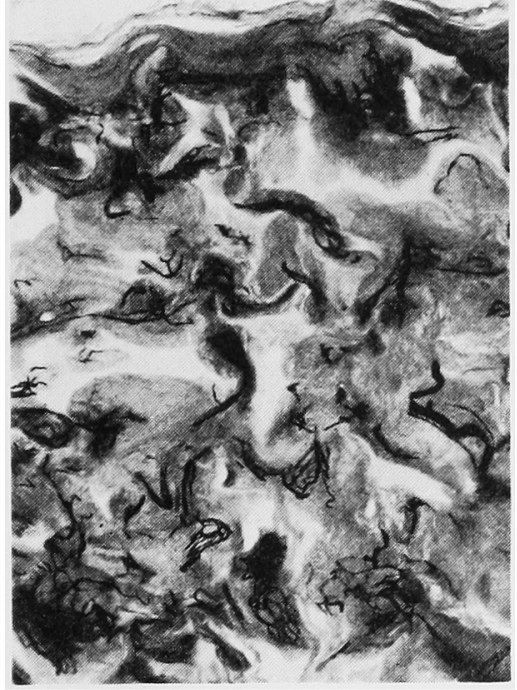

写真 15 コラーゲン固定化群埋入後 20 週 墨汁注入法に上る血管像 (H-E 染色, $\times 40)$

気孔内の毛稩血管は12週よりも增加し複雑，多様に 分吱，吻合した毛細血管網が形成されている。

よって軟組織適合性を得よらとする試みがなされている が，実用化するにはいかに安定かつ強固にコラーゲンを 固定化するかが問題となる。野・岡村ら マ処理によって親水化した材料表面にコラーゲンを物理 的にコートした後, 紫外線照射によってコラーゲン層を 不溶化する方法を試みている。しかしここのらな物理 的固定方法では，コラーダン層が含水環境下で䟝離しゃ すく，その安定性に問題を残している.

一方, 玉田, 岡田 ${ }^{4,5}$ らは材料表面の官能基にコラーゲ ンを共有結合によって化学的に固定する方法を試みてい る、またシリコーンや今回のボリエチレンのように，表 面に官能基をもたない材料の場合には，表面へのプラズ マ処理とポリアクリル酸のグラフト重合を行らことによ り，材料表面にカルボキシル基を導入し，これを介して コラーゲン分子のアミノ基との間にペプチド結合をつく り，材料表面にコラーゲンを固定化することがでる。 この共有結合による方法は，水分の存在下でもコラーゲ ン層が剩離することがないため，現時点では理論的に最 も強固なコラーダンの固定化法と考えられている。 しか し，岡田ら 5 が表面の平滑なコラーゲン固定化試料を動 物内に埋入し，それと軟組織との結合の強さを測定した ところ，わずかに $40 \mathrm{~g} / \mathrm{cm}^{2}$ であり，コラーゲンを固定 化としても表面の平滑な材料では軟組織との結合強度に は限界があった：そこで著者は，多孔質材料に本方法を 応用し，気孔内に侵入した組織と材料との機械的嵌合力 も暲せもたせることで，軟組織とのより高い結合力を得 ることを試みた。

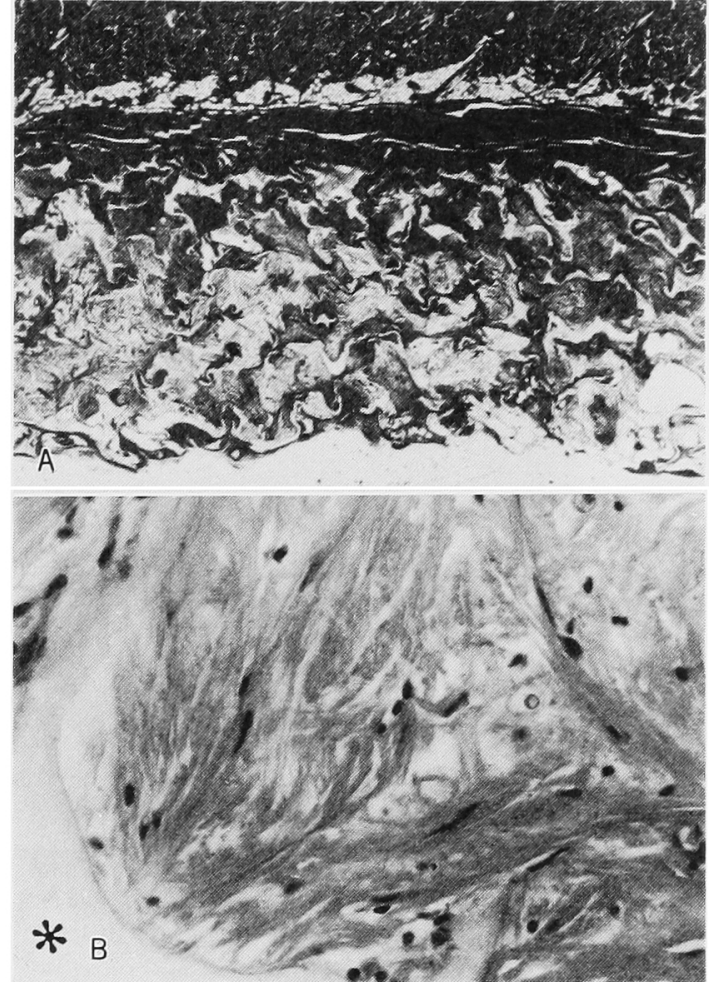

写真 16 コラーダン固定化群埋入後 1 年光顕所見 (H-E 染色)

A：気孔内は全域にわたり結合組織で満たされてい る(x4)

B：気孔内の結合組織の線踓は太く，密度を增し， 材料と組織は密に按している $(\times 200)$. （＼cjkstart卯は材料隔壁を示す）

\section{2. 埋入結果について}

1) 組織侵入度

多孔質材料は気孔内に組織が侵入すると生体組織と一 体化する，いわゆる biocomposite の状態になるため, 生体内に打る人工材料の 1 つの存在様式として注目さ れてきた。臨床的にも形成外科，胸部外科，買顔面外科 領域でさまざまに応用され，ある程度の成果をおさめて きた10 15) しかし，その反面血管の存在しない気孔内部 は，生体の免疫力の及ばない領域として留染を受けやす く，期待通りに組織の侵入が得られず，失敗する例も少 なくない16,17)。このよらな多孔質材料の欠点を改善し， 上記の特性を最大限に発揮させるためにも，気孔内への 組織侵入を促進するための表面改質が必要となる5。今 回のラット皮下埋入実験においてす，未処理のポリェチ レン多孔質材料内では，気孔内への組織侵入度は埋入初 期から 1 年後にいたるまで 13〜18\%ときわめて低かっ た、これに対してコラーゲン固定化群では，明らかに気 


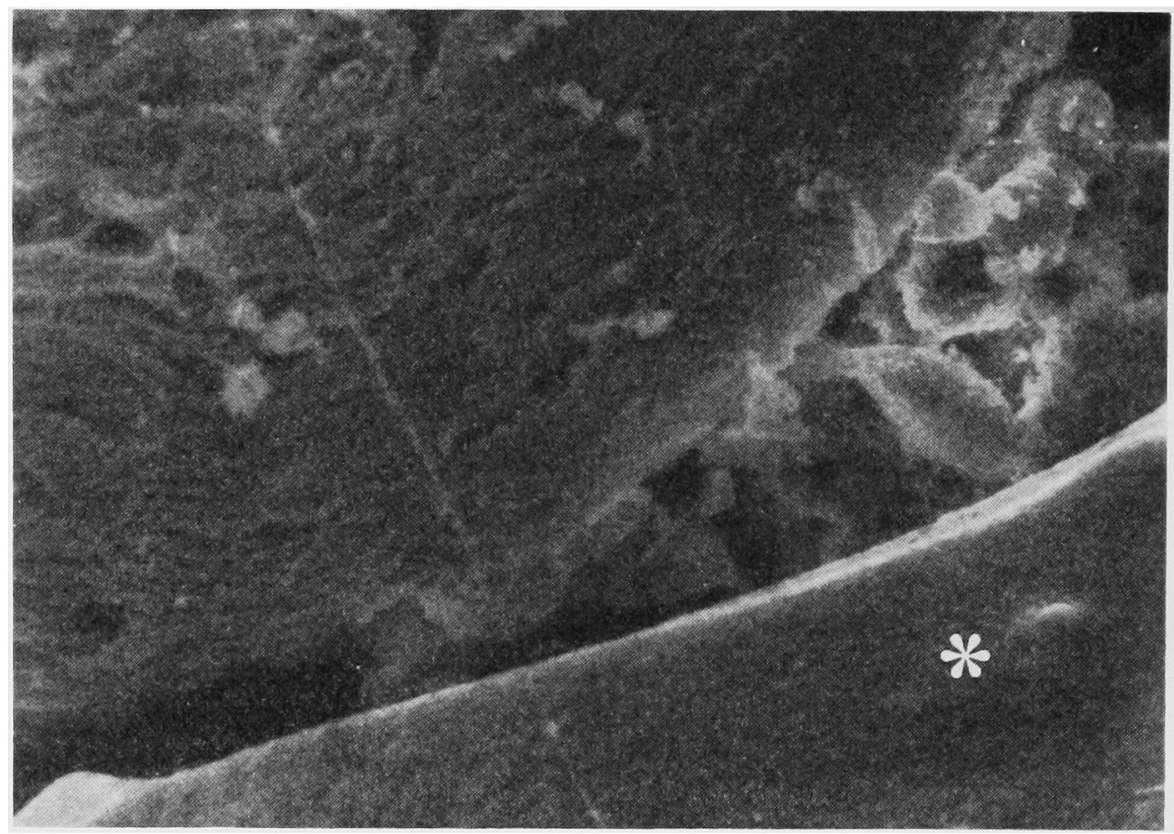

写直 17 未処理群埋入後 1 年の気孔内結合組織と材料の境界部の SEM 所見 $(\times 1,000)$. コラーゲン線維は材料表面に平行に走行し，材料との結合はみられない（＼cjkstart印は材料隔壁 を示す)。

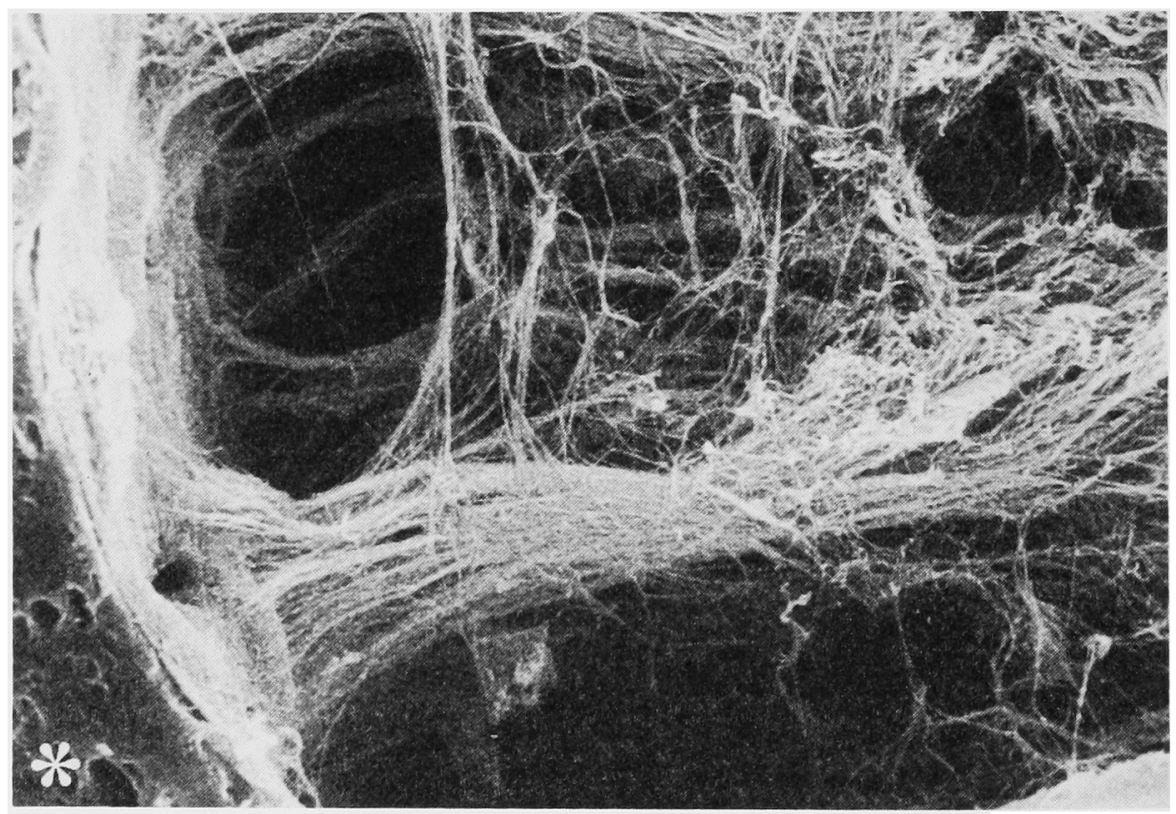

写真 18 コラーゲン固定化群埋入後 1 年の気孔内結合組織と材料の境界部のSEMI 所見 $(\times 1,000)$.

形成されたコラーダンが東状をなして材料表而に結合している(*卧は材料隔壁を示す). 


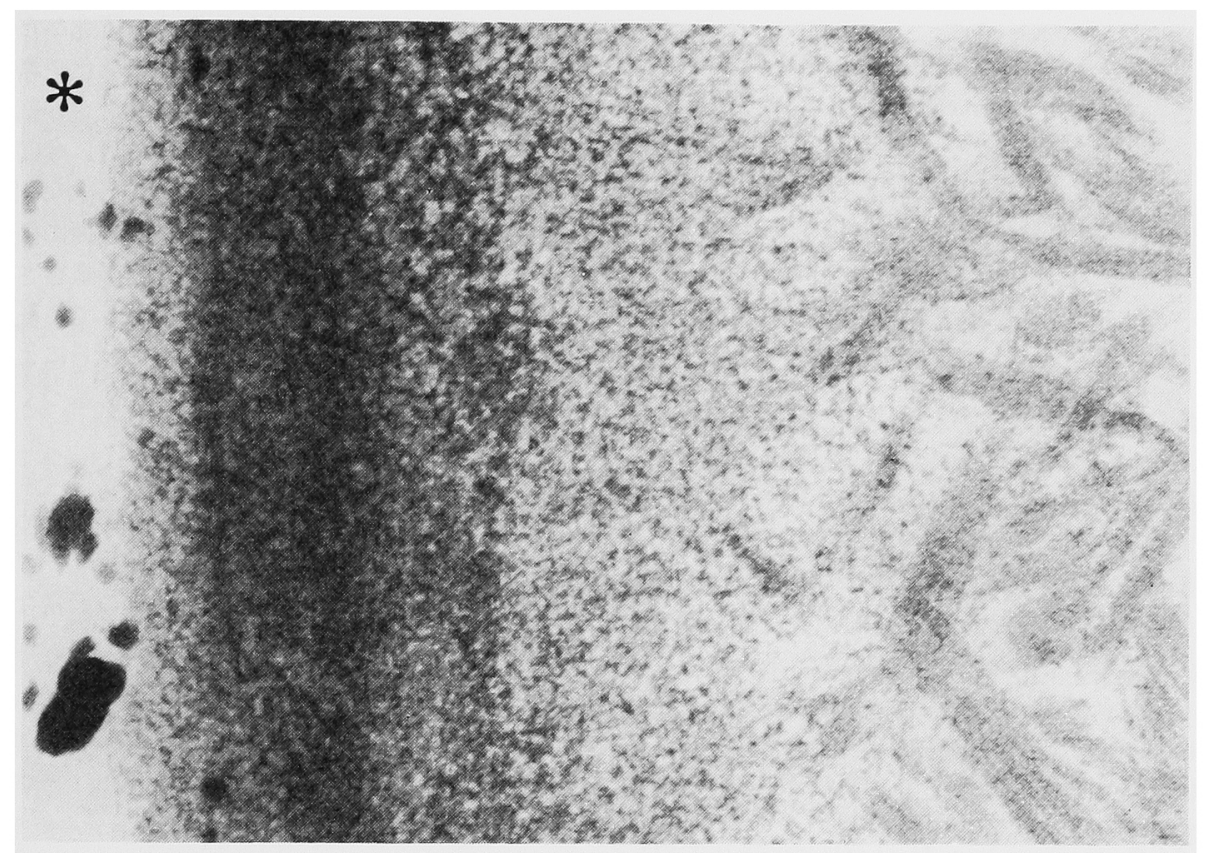

写真 19 コラーゲン固定化群埋入後 1 年の気孔内結合組織々材料の境界部の TEM 所見 $(\times 80,000)$.

周期搆造の明瞭なコラーゲンが材料表面に固定化されたフテロコラーゲン層に絡み合うよ らに形成されている(*印は村料隔壁を示す)。

孔内への組織の侵入が促進され，すでに早期に材料の中 心部まで組織で満たされ，最終観察期間の 1 年後まで biocomposite の状態分維持された。

一般に，多孔質材料内への組織の侵入度は材料の孔 径, 表面の濡れ性，化学構造などに依存すると考元られ る. 本実験江用いた多孔質材料の平均孔径は約 $400 \mu \mathrm{m}$ であるがここれは毛細血管を伴った結合組織の侵入には 十分な孔径といえる。 また今回のコラーダン固定化によ る表面改質では，その中間過程でのプラズマ処理および アクリル酸のグラフト重合による表面の濡れ性の変化も 全く無視はできないが，今回のコラーゲン固定化群の組 織侵入の著しい向上には, 気孔内面に最終的に共有結合 によって固定化されたコラーダンが組織侵入の足場とし て重要な役割を果していると考方られる。この点に関し ては，玉田ら立によるプラズマ処理単独括よびアクリル 酸グラフト重合処理だけでは, 組織侵入度の改善がみら れなかったという結果とす一致する。

\section{2) 気孔内の組織構築}

侵入した組織が本来の組織形態を保つことは，多孔質 材料の生体内での最も好ましい存在様式と考えられる。

しかし，一般に人工材料界面では被膜や肉芽組織が形成 し，正常な組織分化の行われないことが知られている。

今回の未処理群では, 気孔内で出血や资症性細胞浸潤
を伴った肉芽組織，あるいはその高度の硝子化がみられ るように，未処理の気孔内が組織分化沉とって不自然な 環境であることを示している。これに対しコラーダン固 定化群では，気孔内の大部分が材料周团の生体組織と同 様の疎性結合組織あるいは脂肪組織で満たされていた。 また，材料中心部にまでも毛細血管網が形成されるな ぞ, コラーダンによる表面改質が気孔内での正常な組織 分化をむたらしたと思われる. しかし，一般にコラーゲ ンは生体内で分解して，吸収されることから，果たして 表面改質効果に 持続性があるかといらことが問題とな る.この点に関して，今回少なくとも埋入 1 年後の最終 観察時点までは, 上記の組織棈造が維持され, 材料周团 から材料を穿通して豊富な血管網の構築が観察された。 このような所見は, 軟組織結合能を長期間保持し, 材料 周囲の血行不良による被覆軟組織の菲薄化, 材料の露出, 感染などといら問題の解決の可能性を示するのと考えら れる。

今回の実験では, 酵素処理によりコラーダン分子末端 のペプチドを除去して抗原性を減じたアテロコラーゲン を用いたが，材料周囲には長期にわたり多核巨細胞が観 察された，本研究ではとの原因を究明するところまでは いたらなかったが，未処理群でる同様の所見がみられる こと，拈よび一般に多孔質材料周囲には同種の充実材料 


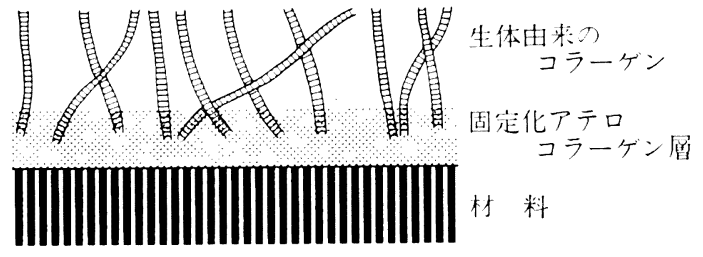

図 2 材料・組織界面の模式図

に比べ，多数の多核巨細胞が出現するとの報告もあるこ とから ${ }^{(5)}$ ，材料の形態的因子によるとも考えられる。特 に生体組織と多孔質材料が biocomposite を形成する過 程では，まず組織液が気孔内に侵入し，ついで組織細胞 の侵入が起こると考えられるが，Eriksson ら ${ }^{19)}$ は死腔内 に貯留した組織液中にマクロファージの走化性を誘導す る物質の生成されることを報告している。したがって， 今回のような比較的大きな多孔質材料では, 気孔内部の 組織液中にこの種の物質の存在したことも考えられる が，詳細は今後の検討課題である。

3) 材料之組織之の界面の微細構造

軟組織絬合能を考える場合，組織かいかにして材料と 結合するかは重要である。

未処理群の場合, 結合組織線䌖は材料表面に平行に走 行しており，材料とは何らの結合も認められなかった。 これに対しコラーゲン固定化群では，SEM 像で明らか なよらに材料表面に垂直的に走行する多数の線維構造が 又られまた材料界面の TEM 像では, 1 年後も周期構造 の明らかな生体由来のコラーゲン線維と固定化アテロコ ラーゲン層との移行がみられた。これらの所見を模式化 すると図 2 のごとくとなり，このよらな構造はこれまで の材料にはみられなかったものであり，軟組織と材料と の接着様式として重要な知見と考学られる。

4) コラーケ゚ン固定化による腫瘍形成の抑制

一般にラットなどのげっ歯類の皮下に長期間，高分子 材料を埋入すると，材料の種類によらず高率に発癌する ことが知られている 20 31). 今回の長期埋入実験でも未処 理群では，1年後に埋入試料の $45 \%$ にヒトの悪性線維性 組織球腫にきわるて類似した腫瘍が形成された。これに 対しコラーゲン固定化群のそれは $5 \%$ と低く，明らかな

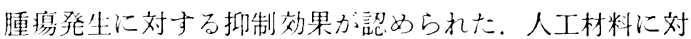
する異物発癌の研究はこれまてにも数多くなされている が，その原因については現在，明らかていない。

一般に血行を保ちにくい:ート状の材料が，メッシュ 状の材怗よりも発癌しやすいことが報告されている30). また今井ら ${ }^{31,32)}$ は，材料周囲の被膜の厚さと発癌率との 関俰から，被膜の厚いものでは血行不良による代謝障害 をきたし，このことが異物発癌と密接に関俰しているこ とを指摘している。一方，清水ら ${ }^{33}$ は不活性な材料表面 之細胞之の接触が練胞の分化過程を王め，発癌にいたら
しめると述べている。近年, 多くの研究から細胞と種々 の細胞外基質との接着による細胞の分化や增殖の調節機 構が明らかにされるにつれ，コラーゲンの細胞分化に果 たす役割の重要性が指摘されている34). 今回の実験結果 と諸家の 報告を考え併せると，コラーゲン 固定化群の 腫瘍形成に対する抑制効果は，材料表面に固定化された コラーゲンのために正常な細胞分化が阻害されなかった こと，材料上のコラーゲンを足場として気孔内で良好な 組織構築がなされたこと，そしてこれらによって材料内 外の十分な血行が保たれたことなとに基つくと考えられ る。

ラットにおける異物による腫瘳形成は，ヒトにおいて はそれほど起こらないと考えられているために，両者を 同一に扱らことはできない。しかしコラーゲンによる材 料表面の固定化は, 少なくとも細胞の異常な分化と增殖 の可能性を減じるといら点でも好ましい表面改質とい壳 よ5.

結語

材料表面に共有結合によってアテロコラーゲンを固定 化したポりエチレン多孔質材料を 1 年にわたってラット の背部皮下に埋入した。その生体内組織反応を組織学的 および電顕的に観察し以下の結果を得た。

1. 気孔内組織侵入度は未処理群では埋入 1 週から 1 年後にいたるまで，13１8\%の間でほぼ一定であった。 それに対し固定化群の組織侵入度は埋入 1 週で $23.2 \%$ ， 2 週で $32.4 \% ， 4$ 週で $60.2 \% ， 6$ 週で $69.3 \% ， 12$ 週で $81.6 \%$ であり，20週後も 1 年後も $90 \%$ 以上と高值を維持 していた。

2. 未処理群ではその周囲に埋入後 20 週まで炎症性細 胞浸潤が残存するのに対し，固定化群ではより早期に炎 症性細胞浸潤は消退する傾向がみられた。また未処理群 では気孔内に侵入した組織は肉芽様組織で, 材料と組織 とは離開し，その間に死腔が存在していた。これに対 し, 固定化群の気孔内組織の大部分は毛紐血管に富む柾 性結合組織からなり，組織と材料とは密に接していた。

3. 墨汁注入法による血管像の観察結果は次の通りで ある。未処理群では12，20週とも気孔内に毛細血管が散 在するのみで，しかもそれらは孤立性であったのに対 し, 固定化群では12週で毛細血管は気孔のほぼ全域に形 成され，20週ではさらに血管量が增加し，気孔内には複 雑に分岐した血管網が観察された。

4. SEMによる観察結果では, 未処理群では埋入 6, 20 週, 1 年後と屯, コラーゲン線維は材料と平行に走行 し，材料との結合が認められなかったのに対し，固定化 群では埋入 1 年後もコラーゲン線維は材料表面に向かっ て重直に走行し，これに付着していた。

固定化群の材料と組織との界面との TEM 像には, 
埋入 6 週後から固定化したアテロコラーダン層に生体由 来のコラーゲン線維が絡み合っているのが観察され，埋 入後 1 年まで同様な所見が観察された。

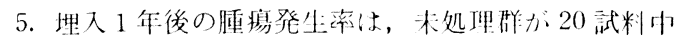
9 試料 $(45 \%)$, 周定化作力2 20 欲料小1 试料 $(5 \%)$ てあ な。

以上のように，人工忉料表面にコラーゲンを基有結合 によって固定させる力法は，材料にこれまで認められな かった軟縕織結合能を付与し，しかもその效果が少なく とも1年といら長期にわたって維持されることが確認さ れた。さらに本法は，腫瘍の発生にも抑制効果があり，

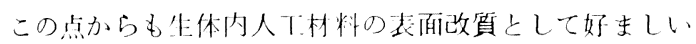
方法と結論する。

稿孛終えるに古たりこ懇篤なこ指導，こ校閲をいたた いた神奈川荫科大学口四空外科学教空志村介三教授に深甚

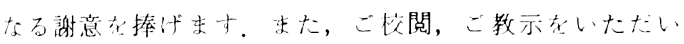
た本学口腔解剖学教空高楅和人教授, 口腔生化学教空教

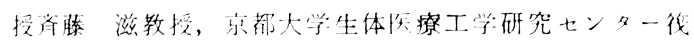
我人教授に深㴬いたします。さらに本研究におした，終

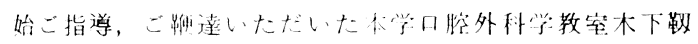

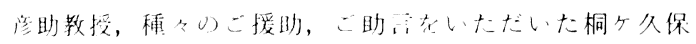

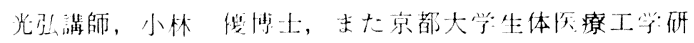
究センター阔田解行捗士に深く感謝したします。また， こ支援、こ坮力在いたたいた本学口腔解剖学教窒高橋常 男講師，下里值引士訬士上ひ教宂の諸先生方に謝意老表 します.

本論文の要旨汁, 第34回日本口腔外科学会総会（平成

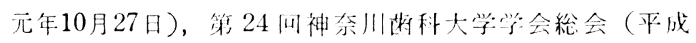
元年12月10日)，第４４同日本口腔利学会絰会（平成 2 年

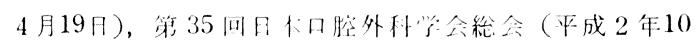

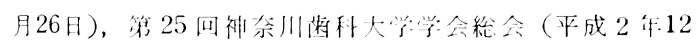
月8日) 一执して発表した。

\section{引用文献}

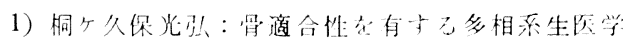
材料に関与る研究一籍 2 報一イドロキシア 夕イト合成高分子複合材料の生体内組織反応 について一。目几外誌 32：1561-1580 1986.

2) 消水慶应, 寺松 孝, 他：コラーダン合成高分 子複合体の研究一層状複合体の組緎親和性につ いて一。 人工缄器 4: 349-356 1975.

3）日野常和，岡村誠三。生体材料としてのコラー ゲンープラスチックス䙓合体。生体材料 1：5 161983.

4) 五田纷，岡田能行，他：表而にーラーゲン充 グラフトしたポリエチレンスポンジのラット皮

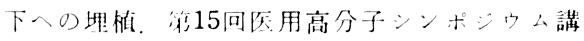
演要旨集：89-90 1986.

5) Okada, T., Tamada, Y., el al.: Surface modification of silicone for tissue adhesion. Biomaterials and clinical applications: 465 4701987.

6) Suzuki, M., Kishida, A., et al.: Grafı copolymerization of acrylamide onto a polyethylene surface pretreated with a glow discharge. Macromoleculs 19(7): 1804-1808 1986.

7) Kleinman, H.K., Klebe, R.J., et al.: Role of collagenous matrices in the adhesion and growth of cells. J C'ell Biol 88: 4731981.

8)大鼠辛, 小出輝, 他: コラーダンの抦態生

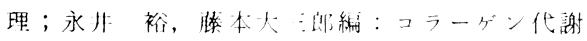

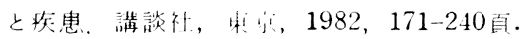

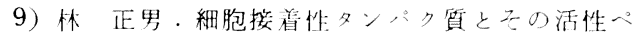
プチド 生体の利学: 41：103-107 1990.

10) Edgerton, M.T. and McClary, A.R.: Augmentation mammaplasty.-Psychiatric implications and surgical indications with special reference to use of the polyvinyl alcohol sponge (sponge). Plast Reconstr Surg 21: 279-305 1958.

11) Pangman, W.J. II. and Wallace, R.M.. The use of plastic prosthesis in breast plastic and other soft tissue surgery. Westem Journal of Surgery Obstetrics and Gynecology Aug: 503-512 1955.

12) Lewin-Epstein, J.: Use of polyvinyl alcohol sponge in alveoplasty; A preliminary report. J Oral Surg 18: 453-460 1960.

13) Rob, ('.G., Eastcotl, H.H., et al., The reconstruction of arteries. Br J Surg 43: 4494661956.

14) Berghaus, A.: Porous polyethylene in reconstructive head and neck surgery. Arch Otolaryngol 111: 154-160 1985.

15) Shaber, E.P.: Vertical interpositional augmentation genioplasty with porous polyethylene. Int J Oral Maxillofac Surg 16: 6786811987.

16) Peters, W.J. and Smith, 1).C. I Ivalon breast prostheses; Evaluation 19 years after $1 \mathrm{~m}$ plantation. Plast Reconstr Surg 67(4): 5145181981.

17) Bolton-Maggs, P.H.D. and Motson, R.WI: Late presentation of polyvinyl alcohol sponge (Ivalon) aortic graft failure. Thorax 34 : 561-562 1979.

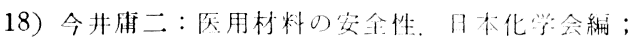
化学総説21。学余活版七ン夕一, 東京, 1987, 55-84面.

19) Eriksson, A.S., Bjursten, L.E., et al.: Hollow implants in soft tissues allowing quantitative studies of cells and fluid at the implant interface. Biomaterials 9: 86-90 1988. 
20) Oppenheimer, B.S., Oppenheimer, T., et al.: Sarcomas induced in rats by implanting cellophane. Proc Soc Exp Biol Med 67: 33-34 1948.

21) Oppenheimer, B.S., Oppenheimer, T., et al.: Malignant tumors resulting from embedding plastics in rodents. Science 118: 305-306 1953.

22) Oppenheimer, B.S., Oppenheimer. T., et al. lurther studies of polymers as carcinogenic agents in animals. Cancer Reseach 333-345 1955.

23) Oppenheimer, B.S., Oppenheimer, T., et al.: The latent period in carcinogenesis by plastics in rats and its relation to the presarcomatous stage. Cancer 11: 204-213 1958.

24) Oppenheimer, B.S., Oppenheimer, T., et al.: Carcinogenic effect of imbedding various plastic films in rats and mice. Surgical Forum 4: 672-676 1954 .

25) Brand, K.G., Bouen, L.C., et al.: Etiological factors, stage, and the role of the foreign body in foreign body tumorigenesis. A review. Cancer Res 15: 279-286 1975.

26) Brand, K.G., Buoen, L.C., et al.: Foreignbody tumorigenesis induced by glass and smooth and rough plastic. Comparative study of preneo plastic events. J Natl Cancer Inst 55: 319-322 1975.

27) Carter, R.L. and Roe, F.J.C.: Induction of sarcomas in rats by solid and fragmented polyethylene; Experimental observations and clinical implications. $\mathrm{Br} J$ Cancer 23: 4014071969.

28）前川昭彦・・イオマテリフルの生体組織反応。 病態生理 3：372-378 1984 .

29）不川隆俊，高山昭三：異物に上万発瘦。痛の科 学: 2. 太田邦夫, 山本正, 他編：環境之発癌。 南江堂, 東京, 1979, 215-228頁。

30) Halpern, B.D.: Polymers in medicine and surgery-A survey. Annals New York Academy of Sciences 146: 193-201 1963.

31) 今井朋二：高分子に上る発癌の機構高分子学会 編; 矢療機能材料。共文出版, 東京, 1990, 9397頁.

32) Imai, Y. and Masuhara, E.: Long-term in vivo studies of poly (2-hydroxyethylmetha (rylate). J Biomed Mater Res 16: 609-617 1982.

33）消水鹿彦，平井表一，他：合成高分子材料埋植 に上万発瘦と collagen 被酺に上る発癌抑制。 人工荿器 18: 76-79 1989.

34）榎並淳平：乳腺分化に打计万細胞外マトリック 入，細胞工学 8：166-173 1989. 